\title{
The number of cultured heterotrophic bacteria and the total bacterial number in the surface microlayer, water column and epilithic biofilms of the littoral zone of Lake Baikal
}

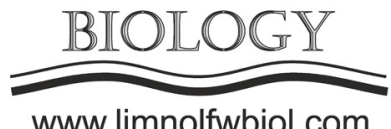

\author{
Zimens E.A.*, Sukhanova E.V., Belykh O.I. \\ Limnological Institute SB RAS, Ulan-Batorskaya 3, Irkutsk, 664033, Russia
}

\begin{abstract}
We have shown that the number of heterotrophic bacteria in the surface microlayer and periphyton is reliably higher than in the water column, which characterizes these biotopes as sites of intense destruction of suspended organic matter. Average values of the total bacterial number, the number of cultured heterotrophic bacteria and the $\mathrm{K}$ index indicate the elevated supply of labile organic matter at the stations near the Listvyanka settlement, the Olkhonskiye Vorota Strait and Aya Bay.
\end{abstract}

Keywords: heterotrophic bacteria, total bacterialnumber, biofilms.

\section{Introduction}

Heterotrophic bacteriocenoses, especially periphyton, havea widerange of adaptivecapabilities and a quick response to changing environmental conditions, which is reflected in the abundance fluctuations and changes in the structure of aquatic bacteriocenoses. In other words, they can serve as indicators in the studies of the anthropogenic pressure on the aquatic ecosystem (Oleinik, 1997; Flemming, 2002). Bacteria capable of growth on culture medium represent the most reactive component of bacteriocenosis, which quickly responds to all environmental changes. As a rule, with an increase in the trophic level and the degree of water pollution, the proportion of cultured forms of bacteria also increase.

\section{Materials and methods}

In August 2017-2019 during the fieldworks (RV "G. Titov"), the samples were taken from the following stations: opposite the Bolshiye Koty settlement (51 $\left.{ }^{\circ} 53^{\prime} 93.0^{\prime \prime}, 105^{\circ} 03^{\prime} 83.8^{\prime \prime} ; 51^{\circ} 54^{\prime} 05.4^{\prime \prime}, 105^{\circ} 04^{\prime} 07.9^{\prime \prime}\right)$, The Bolshoye Goloustnoye settlement $\left(52^{\circ} 01^{\prime} 20.8^{\prime \prime}\right.$, $\left.105^{\circ} 23^{\prime} 98.4^{\prime \prime} ; \quad 52^{\circ} 01^{\prime} 22.0^{\prime \prime}, \quad 105^{\circ} 23^{\prime} 98.7^{\prime \prime}\right)$, the Olkhonskiye Vorota Strait ( $53^{\circ} 00^{\prime} 91.5^{\prime \prime}, 106^{\circ} 55^{\prime} 72.2^{\prime \prime}$; $\left.53^{\circ} 00^{\prime} 91.3^{\prime \prime}, 106^{\circ} 55^{\prime} 73.1^{\prime \prime}\right)$, near Aya Bay ( $52^{\circ} 49^{\prime} 83.1^{\prime \prime}$, $\left.106^{\circ} 42^{\prime} 22.3^{\prime \prime}\right)$, Izhimey Cape $\left(53^{\circ} 13^{\prime} 06.2^{\prime \prime}\right.$, $\left.107^{\circ} 39^{\prime} 34.7^{\prime \prime}\right)$ and Listvennichny Bay $\left(51^{\circ} 50^{\prime} 66.0^{\prime \prime}\right.$, $\left.104^{\circ} 52^{\prime} 45.7^{\prime \prime}\right)$; the central station of the ListvyankaTanhkoy transect $\left(51^{\circ} 42^{\prime} 94.8^{\prime \prime}, 104^{\circ} 59^{\prime} 20.0^{\prime \prime}\right)$. At each station, water samples were taken from various depths, from 0 to $25 \mathrm{~m}$, using a bathometer and a winch. Additionally, at each station, the scuba divers from Limnological Institute collected into sterile containers three rocky substrates with fouling (biofilms) from depths of $12-20 \mathrm{~m}$. Near-bottom water was sampled into sterile syringes near the taken substrates.

Water samples were inoculated in a volume of 1 $\mathrm{cm}^{3}$. Periphyton from rocky substrates was scraped off in the aseptic conditions $\left(2 \mathrm{~cm}^{2}\right)$, which was followed by the preparation of ten-fold dilutions and their use for microbiological duplicate plating. Using various culture media and cultivation conditions, the abundances of the following bacteria was determined: organotrophs (fish peptone agar $/ 1022^{\circ} \mathrm{C}$ ), psychrophiles $\left(\mathrm{R}_{2} \mathrm{~A}, 4-8^{\circ} \mathrm{C}\right.$ ) and oligotrophs $(0.001 \%$ maximum available discharge, $22^{\circ} \mathrm{C}$ ).

\section{Results}

From 2017 to 2019, the WMW test (WilcoxonMann-Whitney test) did not statistically reveal reliable differences between the average abundances of organotrophic, oligotrophic and psychrotolerant bacteria in the surface microlayer (SML), water column and epilithic biofilms from all studied stations (with $\mathrm{p}<0.05$ ). In this regard, Table 1 shows the average values that are valid for all groups of bacteria.

The average numbers of the main cultured heterotrophic bacterial groups for the water column were comparable; there were no significant differences between 2017, 2018 and 2019 (the WMW test, p > 0.05). Notably, the average number of heterotrophic bacteria 
Table 1. Average numbers of cultured heterotrophic bacteria in surface microlayer $\left(\mathrm{CFU} / \mathrm{cm}^{3}\right)$, water column $\left(\mathrm{CFU} / \mathrm{cm}^{3}\right)$ and epilithic biofilms of Lake Baikal (CFU/ $\mathrm{cm}^{2}$ ) from 2017 to 2019.

\begin{tabular}{|c|c|c|c|c|}
\hline Biotopes & Bacterial groups & 2017 & 2018 & 2019 \\
\hline Surface microlayer & $\begin{array}{l}\text { organotrophs } \\
\text { psychrophiles } \\
\text { oligotrophs } \\
\text { alue }\end{array}$ & $\begin{array}{c}114151 \pm 10289 \\
53858 \pm 3823 \\
45212 \pm 5689.5 \\
71074 \pm 6600\end{array}$ & $\begin{array}{c}1592 \pm 231.2 \\
52542 \pm 1324 \\
3000 \pm 239.5 \\
19045 \pm 598\end{array}$ & $\begin{array}{c}5365 \pm 987 \\
820 \pm 101 \\
1363 \pm 235 \\
2516 \pm 410\end{array}$ \\
\hline Water column & $\begin{array}{l}\text { organotrophs } \\
\text { psychrophiles } \\
\text { oligotrophs } \\
\text { alue }\end{array}$ & $\begin{array}{c}391 \pm 43 \\
254 \pm 11.4 \\
138 \pm 8.5 \\
261 \pm \mathbf{2 1}\end{array}$ & $\begin{array}{c}236 \pm 4.5 \\
141 \pm 3.4 \\
198 \pm 10.5 \\
191 \pm 6.1\end{array}$ & $\begin{array}{c}63 \pm 12 \\
20 \pm 7 \\
65 \pm 12 \\
49 \pm 9.3\end{array}$ \\
\hline Epilithic biofilms & $\begin{array}{l}\text { organotrophs } \\
\text { psychrophiles } \\
\text { oligotrophs } \\
\text { ralue }\end{array}$ & $\begin{array}{c}126748 \pm 11760 \\
180067 \pm 21090 \\
55328 \pm 4950.5 \\
\mathbf{1 2 0 7 1 4} \pm \mathbf{1 2 6 0 0}\end{array}$ & $\begin{array}{c}11095 \pm 1230 \\
55349 \pm 13900 \\
40854 \pm 1100 \\
35766 \pm \mathbf{5 4 1 0}\end{array}$ & $\begin{array}{c}38417 \pm 5431 \\
924 \pm 134.4 \\
475 \pm 59 \\
\mathbf{1 3 2 7 2} \pm \mathbf{1 3 1 9} \\
\end{array}$ \\
\hline
\end{tabular}

in SML and periphyton was reliably higher than in the water column, which was valid for the three years (2017, 2018 and 2019), ( $<<0.05)$.

The interannual number of heterotrophs (from 2017 to 2019) from SML and epilithic biofilms was reliably different $(\mathrm{p}<0.05)$ (Table 1$)$. There were no reliable differences in average numbers of heterotrophic bacteria in SML and biofilms (with $\mathrm{p}<0.05$ ).

An analysis of the number of heterotrophic bacteria in the water column (from 0 to $25 \mathrm{~m}$ ) revealed their maximum average values at the stations near the Listvyanka settlement, the Olkhonskiye Vorota Strait and Aya Bay, which were $724 \pm 234,783 \pm 280$ and $902 \pm 289 \mathrm{CFU} / \mathrm{ml}$ (Table 2). The total bacterial number in the water column varied from $0.61 \pm 0.15$ to $1.91 \pm 0.5 \mathrm{CFU} / \mathrm{ml}$. Like for the number of the cultured heterotrophs, we recorded the maximum average values of the total bacterial number near the Listvyanka settlement, the Olkhonskiye Vorota Strait and Aya Bay.

The $\mathrm{K}$ index varied from 1396 to 3318; the minimum value of 1396 was recorded at the station near the Listvyanka settlement, and the maximum value of 3318 - near the Bolshoye Goloustnoye settlement.

\section{Discussion and conclusions}

The high abundance of cultured heterotrophs in neuston and periphyton, unlike that in plankton, can be due to the high sorption capacity of these two biotopes, thanks to which there is always a high content of organic substances on the surfaces of solid substrates. Heterotrophic bacterioplankton starts the destruction of organic substances already in the water column; however, a significant part of the suspended organic matter in lake ecosystems sinks to the bottom. Thereby, heterotrophic microbial community (periphyton) is also a highly active site of destruction.

An analysis of the distribution of the total bacterial number and the number of cultured heterotrophic bacteria revealed the maximum average values at the stations near the Listvyanka settlement, the Olkhonskiye Vorota Strait and Aya Bay. This may indicate the elevated supply of labile organic matter to the water body in these areas. The ratio of the total bacterial number and the number of cultured heterotrophs ( $\mathrm{K}$ index) normally serve as a conversion factor for assessing the sanitary state of water bodies. This ratio characterizes the trophic state of the biocenosis. The value of this ratio in waters rich in labile organic matter ranges from $1: 5$ to $1: 100$, whereas in clean water bodies and watercourses, it is much lower and ranges from $1: 100$ to $1: 10000$ (Rheinheimer, 1992). Based on this criterion, all water samples were classified as a clean water body. The average value of the $\mathrm{K}$ index did not reliably differ at all studied stations (the WMW test, $\mathrm{p}<$ $0.05)$. The highest average $K$ value was recorded at the stations near the Bolshoye Goloustnoye and Bolshiye Koty settlements, which characterizes these waters as cleaner than those near the Listvyanka settlement, the Olkhonskiye Vorota Strait and Aya Bay.

Table 2. Average values of the total bacterial number (cells/ml), the number of cultured heterotrophs (CFU/ml) and the Razumov index $\left(\mathrm{I}_{\mathrm{r}}\right)\left(10^{6}\right.$ cells $\left./ \mathrm{ml}\right)$ in the water column of Lake Baikal in August 2019.

\begin{tabular}{|c|c|c|c|}
\hline Station & $\begin{array}{c}\text { Total bacterial num- } \\
\text { ber, } 10^{6} \text { cells } / \mathrm{ml}\end{array}$ & $\begin{array}{c}\text { Number of cultured } \\
\text { heterotrophs (CFU/ml) }\end{array}$ & $\mathrm{I}_{\mathrm{r}}$ (cells/ml) \\
\hline Listvynka settlement & $1.26 \pm 0.38$ & $902 \pm 289$ & $1396 \pm 310$ \\
Bolshiye Koty settlement & $0.61 \pm 0.15$ & $208 \pm 34$ & $2932 \pm 289$ \\
Bolshoye Goloustnoye settlement & $0.75 \pm 0.23$ & $226 \pm 78$ & $3318 \pm 459$ \\
Olkhonskiye Vorota Strait & $1.53 \pm 0.43$ & $724 \pm 234$ & $2113 \pm 400$ \\
Aya Bay & $1.91 \pm 0.5$ & $783 \pm 280$ & $2439 \pm 295$ \\
\hline
\end{tabular}

Note. After the "+" sign, we provide the value of the standard error of the mean at a significance level of 0.05 . 
Therefore, the average number of heterotrophs in SML and periphyton was reliably lower than in the water column, which characterizes these biotopes as sites of intense destruction of suspended organic matter. The average values of the total bacterial number, the number of cultured heterotrophs and the $\mathrm{K}$ index indicate the elevated supply of labile organic matter at the stations near the Listvyanka settlement, the Olkhonskiye Vorota Strait and Aya Bay.

\section{Acknowledgements}

We thank I.V. Khanaev, I.A. Nebesnykh and V.I. Chernykh for their assistance in sampling. The Russian Foundation supported this work for Basic Research, project No. 18-34-00443.

\section{References}

Oleinik G.N. 1997. Bacterioplankton and bacteriobenthos in ecotone ecosystems. Gidrobiologicheskiy Zhurnal [Hydrobiological Journal] 33(1): 51-62. (in Russian)

Flemming H.C. 2002. Biofouling in water systems-cases, causes and countermeasures. Applied Microbiology and Biotechnology 59: 629-640. DOI: 10.1007/s00253-002-1066-9 Rheinheimer G. 1992. Aquatic microbiology. 4th ed. London: Wiley. 